\title{
21 世紀の風工学一成熟社会への対応
}

Wind Engineering in 21st Century

村上 周三 ${ }^{1)}$

予測には一般に、短期予測、中期予測、長期予測の 3 種類があります。 21 世紀の風工学について述べる ということは、いわば風工学の中・長期予測をするこ とにつながると思います。この種の問題で中・長期の 予測をすることは大変難しいことです。たとえば5 0 年前、100年前の風工学の研究状況から現在のそれ を予測してみるという思考実験をしてみれば、その困 難さがよく理解できると思います。

風工学会は日本学術会議にも登録・認証された学術 団体で、大げさに言えば社会の公器であります。した がってその将来計画を検討するにあたっては、まず当 学会と社会との関わりについて考える必要があると思 います。そもそも社会が必要としない学会は存続して いくことは難しい訳です。従って、当学会の中・長期 の将来を構想する際には、 21 世紀の社会がどのよう に変化して行くか、また何を必要とするかということ を予測すれば、答えの多くの部分が自ずから明らかに なってくると思います。

このような文脈で 21 世紀のキーワードは何かと問 われれば、それは人口問題と環境問題ではないかと思 います。エネルギー、資源再循環、安全・防災など各 種のメジャーな研究開発テーマは上記の 2 つの問題に 集約されると思います。風工学の将来の活動方向はこ の点に焦点をあわせるべきであろうと思います。
次に風工学会に縁の深い建設産業について述べます。 GNP に対する建設投資の割合は、先進各国のなかでは 日本が圧倒的に大きいというのは周知の事実です。我 が国における新規の建設投資が減少するのは避けられ ない方向です。その代わりに、既存の建設投資に対す るメンテナンス産業が発展することになると思います。 単なる物づくりの学問に執着していては生き延びるこ とは難しいと思います。

最後に、風工学会の会員に関係の深い大学について 考えてみます。出生率の減少で大学進学者の絶対数が 減少してくるのは止めようのない事実です。また現在 の大学の工学系の定員において、建設系のそれが多す ぎるという指摘も多くのところでなされています。将 来のおける建設投資の減少が確定的であれば反論しに くい指摘です。建設系の大学にも冬の時代がくるので はないかと心配です。メンテナンス産業への対応をふ くめ新しい建設系学部のあり方を模索する必要があり ます。

21 世紀の日本は、地球環境問題を含め風工学に縁 の深いさまざまの分野で成熟社会に入っていくと思わ れます。従って我が風工学会にも成熟社会への対応が 求められていると思います。逆にこの点にこそ風工学 会の将来の活動分野が展開していくものと信じていま す。

\footnotetext{
1) 東京大学生産技術研究所 教授 Professor, IIS, University of Tokyo
} 


\section{1 世紀の風工学の課题}

Subjects on Wind Engincering in 21 st Century

大熊武司 " Takeshi OHKUMA"

\section{1.はじめに}

研究課題について長期展望を考えるのは, 研究者を めざすことを決めた修士課程の終わりの頃以来, 初め てである。もっとも，その時は，「復興：欧米に追い つけ, 追い越せ」という時代の風が強く吹いていたの で,ほとんど苦痛は感じなかった。しかし, 今回は事 情が違う。どちらを向いても風はアゲインストであ る。しかし, 役職者としての責務を果たさなくてはな らないので,「䙳風構造」を中心に命題について考え る。

\section{20 世紀のレヴュー}

よく言われるように，20世紀は「技術の爆発」いの 時代であり, 産業, 社会は大きく発展した。もっとも, そのベクトルはほとんど物質的側面に垂直方向ではあ るが。

いずれにしても，技術が発展するためには，善しあ しは別にして, それを必要とする強い欲求, それも多 くの者に共通するあるいは支持される欲求が必要であ る。耐風構造について言えば，それはより高い建築 物，より大空間の建築物，そしてより長いスパンの橋 梁の実現であり,これを可能にしたのが 1890 年代に おける風洞の出現である(材料、構造解析, 建設技術 等の貢献には言及しない。以下同じ)。もっとも，そ の先行した動機は航空機の開発であり,構造物のため に利用され始めるのは 1930 年前後である。

言うまでもなく,自然を相手にしている耐風構造は 風洞の力だけでは発展出来ない。これを助けたのが流 体力学, 乱流理論, 不規則振動論, 通信 - 制御理論, 確率過程論そして空力弾性論等であり,その基本摡念 が提唱されたのは，17世紀にスタートした流体力学 を除き，いずれも20世紀前半である2131。

これらの譇理論を駆使して構造物の耐風設計理論に 新風を送り込んだのがUWO (カナダ) のDavenportで ある（例えば, " The Treatment of Wind Loading of Tall Building"4!，1966）。そして今、酎風設計理論は成熟期 を迎えている。風洞実験手法もまた、コンピュータに よるシミュレーション手法の追慗を受けている。

\section{21 世紀の課題}

上述したように, 耐風設計理論は終局設計, 信頼性 設計, 疲労設計, 応答制御等の側面を含めて成熟期を 迎えつつあるが,具体化の段階で困ってしまう問題は いろいろ残っている。1つの典型は「地形の影警」で ある。特に内陸部の山間や山頂に建設される送電鉄塔 分野では合理的な入力風モデルの設定で困難に面面し ている。風洞もコンピュータも力不足なのである。品 質の確保を目指した信頼性設計とか性能規定設計につ いても, 強風の特性をはじめとして情報不足は否めな い。モニタリングの閥题もある。風荷重についてのグ
ローパル基準とローカル基漼の調和の問題もある。こ れらへの対応が耐風榡造における当面する 21 世紀の 課題であろう。

20世紀は「技術が爆発した時代」ではあるが，それ はほとんど開発のための技術であった。実際, 地球環 境問題を誘発し, 自然災害問題も相変わらず残してい る。「21世紀の風工学の課题」はこの辺りにあるよう に思える。宇宙への進出も進むであろうが, 地球人の 多くが宇宙空間の中で生活するとは思えないし,「風 の状況」も検討がつかないので，考えないことにす る。

さて、一つの課題として, 優れた耐風設計理論や施 工技術が用意されても社会の協力が得られないと強風 被害は隇らないという事実に着目したい。実際、建築 物の屋根や壁, シャッター等の被災は台風のたびに報 告されているら。被害の拡大あるいは二次災害の元凶 というレッテル付きで。このような事情は風工学の先 進諸国でも同じである。

確かに, 研究者からすれば「華やかなテーマではな い」という問題もあると思われるが, 災害の防止・低 滅には技術の問題だけでなく，国の考え方, 社会の構 造, 個々人の考え方や意識等が密接に関係していると いうことである。換言すれば,エンジニアリングの手 法だけで対応するのではなく, 社会科学 (Liberal arts) の手法が必要であるということである。「リスクマネ ジメントと保険」の問題はその惩橋となろう。

4.おわりに

21 世紀は「安心できる世界づくり」の時代である。 耐風問題のみならず, 防災, 環境, エネルギー等のい ずれの問題についても風工学が積極的にコミットしな ければならない。ただし，その手法はインフレート最 中の情報技術の積極的かつ多角的な利用, 社会科学の 手法の導入等, 従来のエンジニアリング中心の手法か ら脱却した手法でなければならない。 参考文献

1) 森谷正規, 21 世紀の技術と社会, 朝日選書, 朝日新 聞社, 1999 年

2) 日野幹雄, スペクトル解析, 朝倉書店, 1977 年

3) 日野幹雄, 水力一・空力弾性振動, 技術研究所業務 資料, No.66024, 電力中央研究所, 1967 年

4 ) Davenport A.G., The Treatment of Wind Loading of Tall Building, Tall Building, Pergamon Press, 1966年

5 ) 大熊武司, 建築物の住風災害 -100 年の教訓, Risk, No-54, 1999.12

11神宗川大学工学部建築学:科 教授 Professor, Kanagawa University 


\section{これからの風工学 \\ Future of the Wind Engineering}

松本 勝 Masaru Matsumoto

\section{1. まえがき}

20 世紀を科学技術の発展とその活用とすれば、21世 紀は残された課題あるいはそれによって生じた問題の 解決と新たな科学技術の展開といえよう。そのような 中で風工学の今後果たさなければならない役割や新た な展開を考えなければならない。ところでこれからの 科学技術の重点課題として、環境、情報、生命科学の 3 つがあげられている。また広い意味で環境の入ると 思われるが、エネルギー・資源、防災に対しても重要 課題と考えられている。従って風工学の今後の展開も これらの課題とリンクさせていかなければいけないと いえよう。21 世紀といっても、どの程度の将来を対象 とするかによって扱うべき対象領域が異なろう。たと えば 5 年から 10 年程度(短期)のものでは、いまそれぞ れの分野で抱えている課題の解決と技術の発展を図る べきであろうし、10 年から 30 年程度(中期)では、他の 科学技術人の風工学からの積極的な展開が必要であろ うし、50 年から 100 年(長期)では、人間の生活環境、 社会環境の大幅な変革(しているであろう状況)に対応 した取り組みも必要となろう。特に中長期的な展望の 元に今から問題意識と考えられる課題と抽出し、その 取り組みを考えておくことは、大いに意義あるものと いえよう。もちろん、わが国を含め、世界各国の社会情 勢は急速の変化しており、10 年先を見通すことが困難 となっている今日、それより長いレンジの予測と対応 には大きな仮定も必要でありまたそれに伴いエラーも 含まれることも確認しておかなければならないが、そ れぞれの時点での修正による展開が必要であることは 論を待たない。

\section{2. 風工学における課題（短期的）}

われわれが現時点で抱えている風工学の課題を大き く分類すると、(1)強風の成因と予測、(2)㩐造物との interaction、(3)エネルギー問題、(4)強風防災、(5)環境 問題、(6)その他 になろう。特に(1)、(2)、(4)については、 現在建築分野、土木分野が、大きく関与している課題と いえよう。橋梁構造物に限れば、(1)基礎知識の整理と 関連分野へのその応用、(2)橋梁の耐風性能設計の確立、 (3)超長大橋や合理化橋梁のための新形式橋梁開発、

（4）ケーブル空力振動制御、(5)国内外の各種構造物 の設計基準の統一化、(6)空力挙動予測の精緻化などが 近未来的課題としてあげられよう。

\section{3. 風工学の展開}

今後風工学を超えて関連工学分野への展開を行うた めには、風工学の分野における基礎知識、情報を整理 し、それらを関連工学（流体力学など）あるいは関連 科学分野のものと比較し融合させることにより、現在 抱えている課題の解決を図ったり、あるいは新たなプ ロジェクトの展開、新たな分野への展開が必要であろ う。たとえば、地球環境の悪化が腎念されており、こ のまま推移するとすれば、“50年先は地球は果たし て?”ということになる利、そのためにも今からその 対策を検討することは決して早すぎることはない。人 間は現在、地上に生活の主たる場を求めているが、今 後は、地上以外に、海洋上、海中、海底、地下、宇宙 にも人間の生活空間の場を求め、それぞれの環境にべ ストな形で、環境を悪化することなく展開することを 考えることも 1 つであろう。そのとき、構造工学、風 工学、流体科学さらには、情報、エネルギ一移送、医 学、などのあらゆる分野の研究とそれらの融合が問題 になろう。そのような夢を持ってさらなる展開をはか ることも必要であろう。 


\section{ブラフボディーの空力弾性的不安定振動の更なる研究を!}

Further Studies on Flow Induced-Vibration of a Bluff Body!

岡島 厚 ")Atsushi OKAJIMA ${ }^{\text {") }}$

\section{1.まえがき}

円柱や矩形断面柱のようなブラフボティー(bluff body)周りの流れでは、剥離したせん断層が物体周 辺に逆流領域や剥離バブルを形成し、さらに後流 領域には渦列が放出、形成される。このようなブラ フボティーでは、ある条件下では後流渦や剥離し た流れによって誘起される振動、すなわち空力弾 性的不安定振(flow-induced vibration)が生じる。しか しその振動の発生機構は必ずしも同一ではなく、 不明な事柄が依然残されている。ブラフボティー のうち代表的な断面形状である円柱と矩形柱を例 として、主として流れ方向振動を例にして自励振 動(フラッター)について展望する。

\section{2.円柱の空力弾性的不安定振動}

まず、円柱の振動挙動を考察する。円柱は流れ方 向及び直角方向にも自由に振動出来る。応答振動 特性で知られているように共振換算流速 $V r_{c r}(=1 /$ $S t_{n}$ ) $=5$ 付近の流速領域では、流れに直角方向 (crossflow)に比較的大振幅の振動が生ずる。そして丁度、 共振換算流速の半分の流速 $\left(V r=V r_{c r} / 2\right)$ 付近の領域 では、換算減衰 $C n$ の小さい場合に流れ方向(in-line) 振動が卓越する 2 つ発振領域が認められる。こ のように、流れ方向振動及び直角方向振動はその 発振する流速 $V r$ の領域がそれぞれ異なり、また換 算減衰率 $C n$ の大きさに強く依存する。ここで、構 造物の換算減衰率、スクルートン数 $C n$ は、 $C n=2 m \delta$ $\rho d^{2}(m$ :円柱の単位スパン当たりの質量、 $\delta$ :振動系 の対数減数率、 $\rho$ :流体密度、 $d$ :円柱直径) と表され、 構造物の振動挙動を強く左右し、Cn 值を大きくす れば振動振幅を抑制することが出来る。しかし風 工学以外の分野で水や金属ナトリウムなどが用い られる場合には、質量比 $m / \rho d^{2}$ の值が空気中に較べ 小さく、しかも溶接構造などで構造隇衰が極めて 小さい場合には、 $C n$ 数が 1 程度に極端に小さくな る。このような場合、 $V r_{c r} / 2=1 /(2 S t)$ 付近で流れ方向 振動が発生し易くなる。流れ方向振動は、対称渦と 交互渦の発生を伴う 2 つの流速域があり、その発 生機構についても更なる研究が望まれる。
3. 種々な矩形柱の空力弾性的不安定振動

矩形断面柱においても、それぞれの共振換算流 速 $V r_{c r}$ 及び $V r_{c r} / 2$ 付近の流速域において不安定振動 が生じる。その際、矩形柱の静特性が断面形状によ り大きく変わる中ロピークの存在に留意する必要 がある。臨界断面比より扁平な形状の矩形柱では 前縁剥離せん断層は再付着しないまま後流渦を形 成する。一方、断面比が大きい矩形柱では剥離せん 断層が矩形柱の上下側面に周期的に再付着する流 れパターンが生じる.このように矩形柱の場合、前 縁剥離せん断層とアフターボディーの相互干渉の 挙動には大きな特徵があり、そのため流れ方向振 動の場合にも、断面形状によってその振動特性及 び発生機構が大きく異なって現れる。矩形断面柱 の流れ方向振動についても更なる詳紐な研究が望 まれる。

4. 空力弾性的不安定振動における種々なパラ メータの影響

さらに、上記の円柱や矩形柱の流れ方向振動特 性は、レイノルズ数、乱れ、模型のテーパー比やア スペクト比(模型高さ/直径)によっても異なる。

(1) レイノルズ数の影響 : 特に、臨界レイノルズ数 以上における振動挙動や発生機構の詳細について はほとんど知られていない。

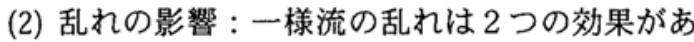
る。1つは、接近する流れの乱れによるバフェッ ティング振動としての効果、2 番目は、表面粗さと 同様に乱れによって臨界レイノルズ数が低下する 効果である。

(3) アスペクト比及びテーパー比の影響: 円柱の静 的特性はアスペクト比によって後流渦の形成、渦 強さ、ストローハル数などは大きく影響を受ける。 さらにテーパー付き有限スパン長さ円柱を片持ち 弾性支持した場合には、振動特性にアスペクト比 やテーパー比の影響が大きく現れる。アスペクト 比やテーパー比による円柱の励振機構と振動円柱 周りの流れ場の 3 次元流れ構造の対応も興味ある 課題であり、更なる研究が望まれる。

1) 金沢大学工学部機能機械工学科 教授 Professor, Kanazawa University 
地形と風ならびに強風災害

Winds over Various Topographies and Strong Wind Disasters

岩谷 祥美 ${ }^{1)}$ Yoshiharu IWATANI ${ }^{1)}$

\section{1. はじめに}

風の研究はここ数十年の間に大きく進歩し、一様な 接地層の風の性質に関しては大きな成果が得られた。 近年は、粗度変化のある領域队複雑な地形上の風、よ り大きなスケールの現象、より高高度の境界層の風に 関心の目が向けられている。

特に、地形と風の関倸については各方面から注目さ れている。地形の複雑性のために、この関係を明らか にすることは容易ではないが、構造物の耐風性の問題、 強風災害の発生、低减、予測の問題、風力発電の立地 の問題など、風に関わる様々な問題を考える際に、風 と地形との関係は重要な課題となっている。

\section{2. 地形と風の研究}

複雑地形と風の研究方法としては 実測、風洞実験、 数值 シミューション などがある。様々な測器が開発され、 実測による研究は進んでおり、実測なしに実体の解明 はできないものの、実測だけでこの問題を全面的に解 明することは難しく、後日誰もが利用できるように研 究成果が整理されて蓄積されていくことが大切である。 数值 ジュレーション は計算機、計算技術の今後の進歩も視 野に入れると、大いに期待できる。たとえぼ台風構造 の数值 ジュレーションの歴史は古いが、気象学的見地から だけではなく、工学的見地からの研究にも期待したい。 たとえば、モデル化された台風が経路に沿って移動す る際の地形影響を受けた風がシミュレートできるなら、 地形と風の関係は広く解明できる。また、台風の発生、 成長、経路などのモデル台風の統計と組み合わせて、

大量の シシューションをを実施すれば、地形の影響を受けた 強風の気候学的な問題にも取り組みが可能であろう。 簡単ではないにしても、地形が多様で複雑なだけに、 台風: 温帯低気圧などの様々な現象の地形影響を含め た大規模な シシューション が現実化されない限り、地形と 風の問題に劇的な進歩を遂げられないのではないだろ うか。もちろん、現段階で精度よい結果はまだ夢では あるが、ここ数十年の研究の歩みをみれば、21世紀 のそう遅くない時期に現実化するように思える。この ときは風だけではなく雨と地形の関係についても詳細 な解析が可能となり、防災上も非常に有効となる。

\section{3. 強風災害}

強風災害は社会の変化とともに、その形態を変える が、その発生件数は少しも減少していない。例えば、 図 1 は気象庁による「気象災害の統計(1971 年 1997 年)」から求めた強風災害の発生件数である（一つの 気像現象の発現に際して各都府県支庁を単位として災 害が発生したときに一件と数える)。㑈然として強風 災害は多数の都道府県にまたがって多数発生している。

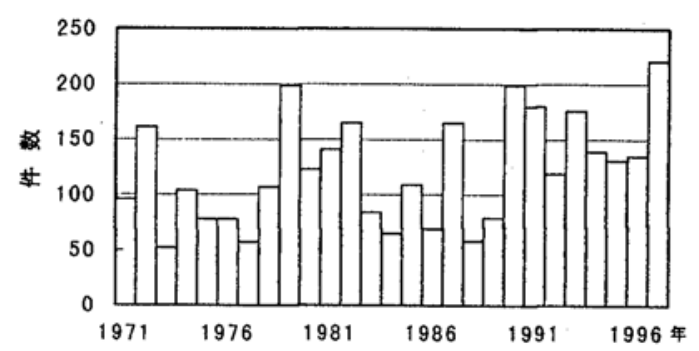

図1強風害の発生件数の推移(1971 1997)

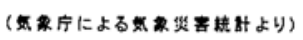

\section{4. 強風およひ強風災害の発生の予測}

現在のような一般的な強風注意報、警報などよりさ らに踏み込んで、地形効果等を取り込んだより詳細な 予測と予報の可能性はどうであろうか。さらに、すす めて地域的な強風災害発生の予測はできないだろうか。 例えば、将来的に、台風の接近に際して、強風と災害 発生の可能性の高い地域が限定的に予測ができれば、 応急的な防災対策、避雃などの即応的な対策の立案が 可能となる。もちろん、実際の予測、予報、防災対策 立案などは気象庁、自治体などの仕事であるが、現時 点ではまだ研究、態勢がそこまで進んでいない。先日 NHKで、アメリカのF EMAという機関の紹介があ り、緊急事態に際して強い権限が与えられ、ハリケー ンの接近時にあらゆる知恵を結集して洪水の予測され る地域の住民に避難命令をだし、現実の避難の指揮に もあたる様子が伝えられた。日本で同様の機関が必要 かどうかは別にして、学際的な研究者集団である風工 学会が、その特徽を活かした研究によって、強風災害 の予測や防止のための基礎的知識を供給することは風 工学会の大切な使命の一つではないだろうか。

1）日本大学生産工学部教授 Professor, Nihon University 
風工学の新しい発展に向けての3つの私見

Toward New Perspectives on Wind Engineering

藤野 陽三” Yozo Fujino ${ }^{1)}$

この四半世紀は, 我が国においては高層建築や長大 橋などの大規模プロジェクトが目白押しであり, 風工学も その恩恵を十分に味わってきた. 構造物作りに直結する 応用的な技術だけでなく，基礎的な研究にも地位が与え られ, 大きな進歩があった. より高く, より長くを可能にす る技術に優先権が与えられた, いわば単純な時代であっ たとも言えよう.

しかし,この延長線上に 21 世紀があるのかと問われれ ば, 種々の状況からして, それは難しかろうと誰もが思っ ている. しかし, これは風工学に限ることではなく, 工学 全体に言えることであり,もう一度,「工学」の原点に戻つ て考えてみる必要がある.

これまでの風工学のかなりの部分は「作るための工学 であった. 我々の生活を豊かにそして安全にするための 風工学といらのが, 今後を考えるにあたり重要な視点であ ろう. その時, 私は以下の3つを思い浮かべるのである.

1) 風エネルギー工学

2) 情報化風工学

3）社会との強いつながり

\section{1. 風エネルギー工学}

地球環境時代の中で, クリーンエネルギーの開発は社 会的要請の高い課題である. 技術の開発の目的が明確 といら意味では, これまでの工学の流れに近いとも言える. 欧米ではかなりの実績があるが, 急峻な地形における風 エネルギーの開発は風況予測から始まって, 発電機構 の効率化, 小型化, 静稻化など我が国の風や社会条件 にあった「独自のもの」の開発の必要に迫られている.

もちろん,これまでに機械系の分野で研究開発されて きた歷史はある. しかし, メディアで騒がれる割には, 地 道な研究は進んでいない. 実際の風を知らずして優れた 風エネルギー工学の発展はあり得ないわけで, 風工学 関係者が貢献できる余地は十分にあろう。

\section{2. 情報化風工学}

構造物の設計においては, 風洞実験で検証するという のがこれまでのやり方である. また, 数值風洞が強力な 武器として揃いつつある,

問題としたいのは, いずれの方法にせよ, 「リアリティの ある風工学が実践されているのかということである.

满造力学で習う「単純ばり」は極めて簡単な構造である が, いかに高度な有限姴素法を用いても, 実物のはりの
挙動を細かいところまでは再現できない. それは真の境 界条件が分からないからである. 実物の挙動を再現する ためにもつとも効果的なのは, 実物の挙動をモニターし て, その情報からモデルを修正することである.

同じようなこと,あるいはそれ以上のことが風の問題に 言えよう. 確かに風は自然現象であり複雑であるが, それ をこのまま放置しておいてよいのだろうか? 実験や数值 解析の精度と入力条件の精度とのバランスがとれていな いと思うのである. 実験や数值解析から出てきた解は正 しくとも, それはカッコつきの解であり, リアリティのある解 とは限らない.

もし, 実際に吹いている風の場の情報が粗くとも, もつ と容易に入手可能になれば, 計算によりミク口な風の場が 揌め, 風エネルギーの予測, 農業, 交通問題などへの利 用が開かれる. オンラインで計算と組み合わせることによ り, 地震時の火災の延焼予測や台風時の避難誘導など の新しい展開も可能になる.

新しい材料が構造物の様相を一変させると言われる. 我々にとっては「風」そのものが「材料」であり, 風のモ二 ターに変革が起これば, 情報化・ハイブリッド化により利 用価値の高い風工学が生まれるに違いない.

\section{3. 社会との強いつながり}

1995 年の阪神大震災では多大の被害が生じたが, 原 因の大部分は, 既存構造物に対する耐震補強の遅れで ある. 進んだ技術の成果が実際の社会に浸透していなか ったことに対する警きが個人的には大きかった。

新しい技術があれば自動的に社会が変わるという認識 は必ずしも正しくはない. 社会を技術という武器で変える という姿勢がエンジニアーに望まれる. それは一つには 設計技術者や他の分野の技術者, さらには一般の人に もわかる形で技術を提供するということである. またものを 決める立場に技術者がもつと積極的に出ていくというス夕 ンスでもある.このことは風工学には限らず, 工学一般に いえることでもある.

新しい技術が渴望されている中で理科系應れが起き ている原因の一部は, 自らが活動の場を狭め, 社会から 見えにくい存在になりつつある我々技術者自身にあるの か吨れない. 若い人が面白そうだと飛び込んでくるよう にするのが何よりも大切と考える.

1）東京大学 厂学系研究科 社会基盤工学尃攻 教授 Professor, University of Tokyo 


\section{1 世紀の風工学 一 建築物の耐風設計 一}

\section{Wind Engineering in the 21st Century - Wind Resistant Design -}

\section{田村 幸雄 ${ }^{\text {1) }}$ Yukio TAMURA ${ }^{1)}$}

\section{1.はじめに}

1960 年代末にアポロ 8 号が、月の地平線（月平 線?) から昇る美しく青い地球 Rising Earth をとらえ ました。地球が、虚空に浮かぶ、極薄の空気層に覆 われた緑と水の小さな惑星で、多くのものが有限か つ微妙なバランスの上に成り立っていることを、改 めて思い知らしめました。この薄膜の、そのまた底 部に起こる擾乱を、耐風工学は相手にしています。

100 年前、江戸時代の生活と大差ない時代の人に とってみると、今のインターネット、新幹線、ジャ ンボジェット機は想像を絶するものでしょう。21 世 紀の 100 年間も、科学技術の更なる発達て時空間の 短緶が限りなく進み、およそ異次元の世界が現出さ れることと思います。次元の違う世界は想像できま せんが、それでも、敢えて矮小な想像力を働かせて、 21 世紀前半の建築物の耐風設計を考えてみました。

2. 建筑物と㓦風設計法の進化

昨今、免震装置、制振装置が建築物に数多く取り 入れられるようになってきました。21 世紀には、モ ニタリングシステム、ウオーニングシステムを取り 入れ、各種のスマートマテリアルを利用し、形態可 変構造システムなどを取り入れたスマート建築物な ども出現し、いわゆる耐風設計队防災対策の考え方 も、従来とは異質のものが要求されるでしょう。耐 風設計法も、これまでの風力低㺂、剛性付加的な考 え方とは異なり、多様化する筈です。

3. 電子データベースと台風シミュレーション

この数十年間用いられてきた基・規準化した風圧 係数や風力係数に基づく耐風設計手法では、複雑な 構造骨組みの部材レベルでの最大荷重効果を的確に 予測することはできません。多点風圧変動情報によ る時刻歷応答解析が必要です。ASCE-98 でも既に取 り入れているように、多点風圧変動の時刻歷が種々 の建物形状について電子データベース化され、ユー ザーがこれらをダウンロードして、時刻歴での応答 /応力解析を行うようになります。さらに進めば、 台風シミュレーションなどとも併用して、崩壊に至 るプロセスを部材レベルの詳細モデルで時々刻々シ ミュレートすることも可能となるでしょう。

形状変化に伴う風荷重変化や風環境変化なども、 双方向データベースシステムにより、瞬時に対応で
きるものとなる筈ですし、自己増殖、自己管理でき るような空力/風データベース、つまりは風工学情 報インフラの構筑が進められるものと思われます。

4. 数值流体モデル/実流体モデルと建物モデル 電子化されたデータベースによる設計も、もう少 し進化すると、数值流体モデルあるいは実流体モデ ルと、建物の有限要素的フルモデルによる連携解析 に変化するものと思われます。数值流体解析の進歩 は言うまでもないことですが、風洞のように実流体 を用いた実験も、決してその重要性を失うことはな いでしょう。実験計測技術の進歩により、3 次元的 な流速場や圧力場の計測が高密度、高速度化すれば、 数值流体解析の持つ情報の豊かさに匹敵し、その重 要性は增すものと思われます。また、大気観測と数 値解析の両方の進歩により、台風内での 3 次元的な 強風構造、あるいはサンダーストームなどの強風構 造もシミュレートできるようになるでしょう。

なお、巨大風洞による建築物の破壊実験の計画が 現在アラバマにあるようですが、むしろ計測技術の 進化、アクティブ制御技術などに期待して、特殊流 体を使ったミクロ風洞などの方に興味があります。 5. モニタリング技術と都市/社会防災システム

高速広带域移動通信システムなどの、より進化し た情報インフラが形成され、かつ航空機や衛星画像 利用技術、GPS 技術などは更に進歩し、大気や地表 の高密度観測が、より正確な気象予知や台風構造の 解明、都市建物群の建築物挙動の一括モニタリング と挙動制御などを可能とします。数值モデルによる 気象予測の精度を上げるのも、観測技術の進歩と正 確な高密度情報の提供が前提です。GPS など衛星利 用のワイヤレス広域監視方式が、都市防災や警報シ ステムのあり方を大きく変えるものと思われます。

6. おわりに

情報インフラの整備や媒体の進化によって、耐風 設計技術はより総合化し、他分野の技術との融合に より、高度に効率的な而風設計システムの構築が可 能となります。日本風工学会も、その果たす役割が より総合化する方向へ向けられ、単なる研究者や技 術者の情報交換の場ではなく、社会への知識と情報 を「サービス」できる機関となる必要がありますし、 途上国の防災対策支援も、重要な課題となります。

\footnotetext{
1) 東京工芸大学工学部建榮学科 教授 Professor, Tokyo Institute of Polytechnics
} 


\section{風工学における CFD の現状とその発展 \\ Current Status of CFD Technique and Its Future Trend in Wind Engineering}

田村 哲郎1) Tetsuro Tamura

\section{1. はじめに}

風工学の分野独自の計算流体力学 (Computational Fluid Dynamics, CFD) も徐々に確立されつつある。風は流 体力学的には高レイノルズ数の乱流であり、構造物ま わりでは流れが剥がれて渦を形成する。したがって広 笵囲のスケールの流れの構造を取り扱う必要があり、 数値解析をする場合は大きな自由度が要求されて大規 模計算になる。また実際の構造物はきわめて複雑な形 状であり、その境界形状を再現しようとすると格子分 割に工夫を要する。さらに風そのものか㵇流場である ので接近する流れに乱れを制御しながら導入する必要 がある。こういった要求が、当初 CFD を風工学の分 野に導入する上で大きな障害となうていた。近年の計 算流体力学の進歩はこういつた問題を解決しつつあり、 ここではCFD の現状と今後について記述する。

2. 複雑形状と一般座標変換

物体まわりの流れを計算する上で、その形状任意性が 取り扱え、また物体表面の境界層が分解できるよう格 子を境界に寄せるということを実現するために一般座 標系の導入が行なわれた。当初この方法に高次精度の 風上差分を組み合わせることによって高レイノルズ数 の流れの数値計算が実現された。しかし、物体まわり の流れのようにカルマン渦が主成分となるような変動 場においては極めて有効であったが、高周波成分も重 要となるような流れ場においてはさらなる解像度が要 求され、計算負荷の点から適用が容易ではなくなった。 十分に細かくない格子に対しては、乱流粘性のモデリ ングの導入が考えられる。ただし、乱流モデリングを 一般座標系での基礎方程式に導入する際、その効果を きちんと評価するための前提条件として、低いレイノ ルズ数での乱流場の DNS において、数值誤差で解を 歪めない計算スキームが必要となり、流れに関する物 理量の保存性が確保できるようなコロケーション格子 あるいはスタッガード格子での計算が行なわれるよう になった (Fig.1) 1)

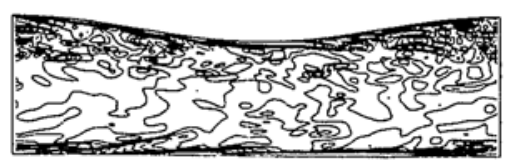

Fig. 1 Turbulent flow between curved and flat surfaces.

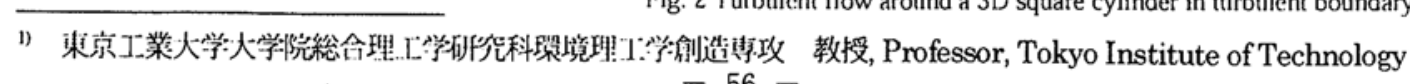

\section{3. 乱流とそのモデリング}

乱流モデリングは、単純な乱流場においては、その理 論的な概念を持ち込むことが比較的容易であるが、物 体まわりの流れにおける剥離せん断層、その不安定化、 さらには後流での渦の形成など、いわゆる複雑乱流に おいては、モデリングの妥当性・汎用性がまだ不明で ある。ただしダイナミックに乱流粘性の定数を決める 方法が提案され、流れ場の特性に応じた乱流モデリン グもある程度可能になってきている。しかしながら、 1995 年に開催された角柱まわりの乱流計算に関するワ ークショップでの複数解の比較によれば 2)、基本的に 格子解像度が十分でなく数值粘性の効果が無視できず、 乱流モデリングの評価というよりは計算スキームによ る差異の方が明膫に出てしまったことから、乱流計算 向きのスキーム開発もこれからの重要課題である。

\section{4. 接近乱流}

一般ににぶい物体の空力特性については、接近流に乱 れが存在すると変化する。これは、剥離せん断層か刺 激を受けて物体に近づくなど、挙動に変化がみられ、 その結果、後流での渦構造あるいは形成位置が変化す るためである。従来の CFD では、ほとんど一様流を 想定していたが、最近は、ドライバ一領域あるいは統 計的手法により流入境界として変動風速を与えること が可能となり、より実際に近い条件でのシミュレーシ ヨンが可能となってきている (Fig.2) ${ }^{3)}$ 。

5. おわりに

これまで風工学の CFD においては、任意形状に対し て一般座標系が導入されたとしても航空工学の延長と しての一様流中の物体まわりの流れであったり、物理 学分野におけるチャネル乱流の延長線上としてのデカ ルト座標系による直方体まわりの流れであり、なかな か風工学的な問題として取り扱われていた訳ではない。 それが、接近乱流の中の複雑形状物体まわりの乱流計 算といった問題が現実となり、風工学独自の CFD が 確立されつつある。
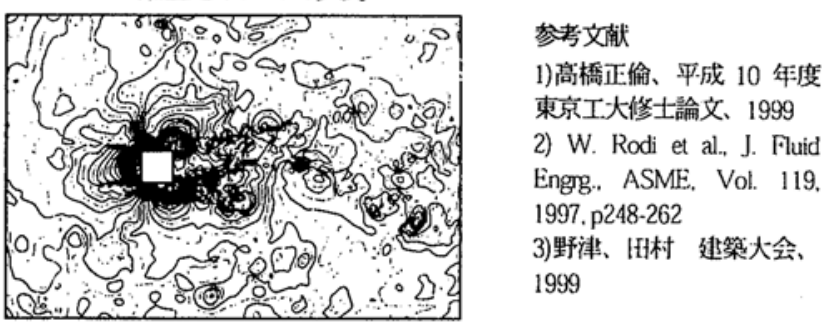
東京丁大借土文 1999 2) W. Rodi et al., J. Fluid Engrg., ASME, Vol. 119. 1997. p248-262

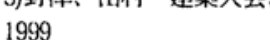

Fig. 2 Turbulent flow around a 3D square cylinder in turbulent boundary layer. 